\title{
Why Do Firms Engage in Selective Hedging? Evidence from the Gold Mining Industry*
}

\author{
Tim R. Adam \\ School of Business and Economics, Humboldt University of Berlin \\ Dorotheenstr. 1, 10117 Berlin, Germany \\ Tel.: (+49 30) 2093 5641; E-mail: tim.adam@wiwi.hu-berlin.de \\ Chitru S. Fernando \\ Michael F. Price College of Business, University of Oklahoma \\ 307 West Brooks St., Norman, OK 73019, USA \\ Tel.: (405) 325-2906; E-mail: cfernando@ou.edu \\ Jesus M. Salas \\ College of Business \& Economics, Lehigh University \\ 621 Taylor Street, Bethlehem, PA 18015, USA \\ Tel: (610) 758-3440; E-mail: jsalas@lehigh.edu
}

June 2015

\begin{abstract}
The widespread practice of managers speculating by incorporating their market views into firms' hedging programs ("selective hedging") remains a puzzle. Using a 10-year sample of North American gold mining firms, we find no evidence that selective hedging is more prevalent among firms that are believed to possess an information advantage. In contrast, we find strong evidence that selective hedging is more prevalent among financially constrained firms, suggesting that this practice is driven by asset substitution motives. We detect weak relationships between selective hedging and some corporate governance measures but find no evidence of a link between selective hedging and managerial compensation.
\end{abstract}

JEL Classification: G11; G14; G32; G39

Keywords: Corporate risk management, selective hedging, speculation, financial distress, corporate governance, managerial compensation.

\footnotetext{
${ }^{*}$ We thank two anonymous referees for their assistance in significantly improving the paper. We also thank Alex Butler, Sudheer Chava, Sean Cleary, Louis Ederington, Gary Emery, Vladimir Gatchev, Janya Golubeva, Dirk Jenter, Swami Kalpathy, Leonid Kogan, Olaf Korn, Zhi Li, Scott Linn, Steve Mann, Gustavo Manso, Bill Megginson, Darius Miller, Thomas Moeller, Fergal O'Connor, Jun Pan, Roberto Rigobon, Martin Ruckes, Antoinette Schoar, Venkat Subramaniam, Rex Thompson, Sheri Tice, Lingling Wang, Pradeep Yadav and seminar participants at MIT, University of Oklahoma, University of Texas at Dallas, Southern Methodist University, Tulane University, Texas Christian University, Humboldt University, ESMT Berlin, the European Finance Association Meetings, the FMA Annual Meetings, the FMA European Conference, the Infiniti Conference, and the German Finance Association Meetings for valuable discussions and comments. We also thank Ted Reeve for providing us with his derivatives-usage dataset of gold mining firms, and Sridhar Gogineni and Leung Kam Ming for excellent research assistance. This research has been partially supported by the Research Grants Council of Hong Kong (Grant No. HKUST6138/02H). Fernando gratefully acknowledges financial support from the National Science Foundation (Grant No. ECS-0323620) and Salas gratefully acknowledges financial support from the Center for Financial Studies, Michael F. Price College of Business. We are responsible for any remaining errors.
} 


\begin{abstract}
The widespread practice of managers speculating by incorporating their market views into firms' hedging programs ("selective hedging") remains a puzzle. Using a 10-year sample of North American gold mining firms, we find no evidence that selective hedging is more prevalent among firms that are believed to possess an information advantage. In contrast, we find strong evidence that selective hedging is more prevalent among financially constrained firms, suggesting that this practice is driven by asset substitution motives. We detect weak relationships between selective hedging and some corporate governance measures but find no evidence of a link between selective hedging and managerial compensation.
\end{abstract}

JEL Classification: G11; G14; G32; G39

Keywords: Corporate risk management, selective hedging, speculation, financial distress, corporate governance, managerial compensation. 
We don't hedge just to say we're hedged, we hedge to make money - Chesapeake Energy Corporation, as reported in a June 4, 2012 Wall Street Journal article "Hedges Gone Awry Set Back Chesapeake" on Chesapeake's recent selective hedging loss exceeding $\$ 750$ million.

\section{Introduction}

Surveys of corporate hedging programs provide extensive evidence that firms around the world routinely speculate within the context of their hedging programs by varying the size and the timing of their derivatives transactions based on managers' market views, a practice known as "selective hedging." ${ }^{1}$ For example, Bodnar, Hayt and Marston (1998), and Glaum (2002) report that the majority of firms in their respective surveys at least sometimes base the size of their hedges on their views of future market movements. Faulkender (2005), Adam and Fernando (2006), Brown, Crabb and Haushalter (2006), and Géczy, Minton and Schrand (2007) also provide empirical evidence that is consistent with selective hedging.

The traditional theories of corporate risk management provide no shareholder valuemaximizing rationale for firms to engage in selective hedging. However, this literature provides numerous theoretical arguments in support of the notion that hedging corporate risk by passively matching one risk exposure with an opposing risk exposure creates value for shareholders by mitigating market imperfections that cause departures from a Modigliani-Miller world. First, hedging can reduce firms' expected costs of financial distress (Smith and Stulz, 1985). This argument also suggests that hedging will help firms increase their debt capacity and the tax shields they can realize from debt (Leland, 1998; Graham and Rogers, 2002). Furthermore, by reducing the cost of financial distress, hedging can also enhance credit quality and reduce the cost of debt financing (Chidambaran, Fernando and Spindt, 2001). Second, when a firm faces a

\footnotetext{
${ }^{1}$ We use the terms "selective hedging," "market timing" and "speculation" interchangeably in the paper.
} 
convex tax function, lowering the volatility of earnings by hedging can help reduce a firm's expected tax burden (Smith and Stulz, 1985; Graham and Smith, 1999). Finally, growth firms that find external financing to be more expensive than internally generated funds could employ hedging practices to reduce the underinvestment problem by ensuring that they have sufficient internal funds available to take advantage of attractive investment opportunities (Froot, Scharfstein, and Stein, 1993) and by reducing the cost to equity holders of financing these investment opportunities externally (Bessembinder, 1991).

In contrast to passive hedging, selective hedging entails managers actively varying the size and timing of their derivatives transactions based on managers' market views. Stulz (1996) proposes a modified theory of corporate risk management, which sets out the two economic criteria that must be satisfied for firms to create value for their shareholders by engaging in selective hedging. First, firms must possess an information advantage relative to the market to add value through market timing. Second, firms need sufficient financial strength to take additional speculative risks based on this information advantage without jeopardizing their core business. To our knowledge, there has been no attempt in the literature to relate the practice of selective hedging to these criteria for value enhancement. Moreover, there has been no investigation of the alternate possibility suggested by Stulz (1996) that, even in the absence of private information, financially distressed firms can be motivated by an asset substitution incentive to engage in selective hedging. ${ }^{2}$

Our research fills this gap in the literature by examining the above questions in the context of the gold mining industry, which has been served as a laboratory for several studies of

\footnotetext{
${ }^{2}$ Campbell and Kracaw (1999) also develop a model where financially constrained firms have an incentive to increase risk exposure.
} 
corporate hedging practices due to the availability of high-quality derivatives usage data. ${ }^{3}$ The gold mining industry is also a particularly good industry to study selective hedging because gold prices are determined by supply and demand in a global market that is largely financially integrated (See, for example, Lucey, Larkin and O'Connor (2014)). The period we examine (1989 to 1999) is a relatively calm period in terms of gold prices but active in terms of changes in hedge ratios (see Figure 1). Thus, changes in gold prices do not drive any abnormal changes in hedge ratios that we interpret as selective hedging because gold prices are relatively flat during our sample period. Alternatively, low gold prices imply that firms are under more pressure to make money by selectively using derivatives because gold mining firm revenues are in large part determined by spot prices unless firms are selectively using derivatives.

\section{[Place Figure 1 about here]}

We find that the extent of selective hedging is positively correlated with a firm's future stock return volatility, which suggests that selective hedging increases risk as surmised by Stulz (1996). We also find a negative relation between selective hedging and firm size, implying that smaller firms speculate more than larger firms. This result stands in stark contrast to our findings for firms in the same sample (and by other researchers in several prior studies) that larger firms are more likely than smaller firms to use derivatives and hedge a higher fraction of their exposure. In robustness checks, we find similar negative relations between selective hedging and two other measures of a firm's footprint in the gold market - its annual gold production and its total gold reserves. In the gold mining industry, firm size, gold production, and gold reserves are

\footnotetext{
${ }^{3}$ We study the derivatives usage strategies of a sample of 92 North American gold mining firms between 1989 and 1999, collected by Ted Reeve of Scotia Capital. This dataset has been extensively whetted in previous studies of the corporate use of derivatives, including Tufano (1996, 1998), Adam and Fernando (2006), and Brown, Crabb and Haushalter (2006). To our knowledge the gold mining industry is the only industry where the data is available in sufficient detail at quarterly intervals to enable a systematic study of corporate speculation with derivatives. Mr. Reeve discontinued his data collection in 1999, which limits our study to the 10-year period ending 1999.
} 
all likely to be positively correlated with an information advantage with respect to the aggregate gold production and hence the future gold price. We also find that selective hedging is negatively related to firm age and CEO tenure, both potential alternate information advantage proxies.

In addition, we find a negative relation between selective hedging and the probability of financial distress, as measured by either Altman's (1968) Z-score or Ohlson's (1980) O-score. Firms with the highest probabilities of bankruptcy tend to speculate the most, which is consistent with Stulz (1996)'s prediction for uninformed firms. These results are the opposite of what one would expect if selective hedging were adding to firm value. Instead, they are consistent with the classical asset-substitution problem first articulated by Jensen and Meckling (1976) and applied to the context of selective hedging by Stulz (1996) and Campbell and Kracaw (1999) as a rationale for more financially constrained firms to engage in activities that increase their risk exposure.

Our findings that firms who are (a) likely to be least informed (smallest) and (b) are closest to financial distress speculate the most should be disconcerting to shareholders and regulators, especially in light of the evidence we provide in this paper that selective hedging increases riskiness, and the evidence provided in previous studies that taking on this additional risk does not provide shareholders any added return even disregarding the cost of managerial time and other resources that selective hedging consumes. ${ }^{4}$

Our findings naturally raise the question of how selective hedging is related to corporate governance. While our overall evidence on this question is weak, the strongest evidence we uncover is a positive relation between the extent of selective hedging and board size. This finding is consistent with the argument (see, for example, Yermack (1996)) that larger boards are

\footnotetext{
${ }^{4}$ See, for example, Adam and Fernando (2006) and Brown, Crabb and Haushalter (2006). To the extent there are scale economies associated with setting up a selective (as opposed to a passive) hedging program, it is surprising also to see smaller firms engaging in more selective hedging than larger firms.
} 
less effective than smaller boards. Another related possibility is that the board puts compensation structures in place that perhaps inadvertently encourage some managers to speculate. For example, Géczy, Minton and Schrand (2007) find that the sensitivity of CFO compensation to stock returns (delta) is positively associated with the probability of actively taking positions (although they find a negative relation for CEOs), In contrast, we find no evidence to suggest that selective hedging in our sample of firms is motivated by managerial compensation structures. This leaves open the question of why managers at smaller firms engage more in selective hedging than managers at larger firms. Graham and Harvey (2001) note that managers at smaller firms tend to be financially less sophisticated than managers at larger firms. Thus, managers at smaller firms may be more likely to erroneously believe that they have an information advantage when, in fact, they do not.

Our study extends previous work on the relationship between speculation and firm value. Using a similar dataset to ours, Brown, Crabb and Haushalter (2006) and Adam and Fernando (2006) find that speculation does not create value for shareholders. Our study takes that evidence as given and explores what types of firms are more likely to speculate. The question we explore in our paper is important because of the results in Brown, Crabb and Haushalter (2006) and Adam and Fernando (2006).

\section{Hypothesis development}

The traditional theory of corporate risk management assumes that firms use derivatives purely for hedging purposes, i.e., without any speculative motives, and that the benefits of hedging accrue solely from the alleviation of market imperfections. ${ }^{5}$ However, there is considerable survey evidence that managers also speculate with derivatives, i.e., incorporate their

\footnotetext{
${ }^{5}$ See, for example, Stulz (1984), Smith and Stulz (1985), Stulz (1990), Froot, Scharfstein and Stein (1993), and DeMarzo and Duffie (1995).
} 
market views into their hedging programs. Bodnar, Hayt and Marston (1998) survey derivatives policies by 399 U.S. non-financial firms and find that about $50 \%$ of their sample firms admit to sometimes (and 10\% frequently) altering the size and/or the timing of a hedge based on their market views. Glaum (2002) surveys the risk management practices of the major non-financial firms in Germany. He finds that the majority follows forecast-based, profit-oriented risk management strategies. Faulkender (2005) examines whether firms are hedging or timing the market when selecting the interest rate exposures of their new debt issuances. He finds that the interest rate exposure chosen is a function of the slope of the yield curve. Adam and Fernando (2006) find considerable evidence of selective hedging in their sample of gold mining firms but find no economically significant cash flow gains, on average, from selective hedging. Brown, Crabb, and Haushalter (2006) also study selective hedging in the gold mining industry and arrive at a similar conclusion. But these studies do not focus much on cross-sectional differences within their respective samples.

Collectively, these studies show that the practice of selective hedging is common in the corporate world. However, the extent to which firms engage in this practice in a manner consistent with firm value maximization remains unclear. For example, it is plausible that at least some firms in this industry may believe they possess an information advantage with respect to the future gold supply and hence the gold price (See, for example, Brown, Crabb and Haushalter (2006)). Firms with a larger business presence in a particular market are more likely to acquire valuable information about this market. Stulz (1996) cites the hypothetical example of a producer of consumer durables using copper as a major input. Such a firm would have a significant incentive to gather information about the demand and supply of copper. Similarly, a large gold producing company with operations across countries or even continents has an incentive and 
ability to acquire information about the determinants of future gold prices. Such information could certainly affect a firm's risk management strategy especially if the firm believes the information is valuable. The extent of any private information a firm acquires is, of course, unobservable. However, larger firms are likely viewed as having a greater potential to acquire valuable information than smaller firms because larger firms can hire better analysts and have a more expansive market footprint. The gold mining industry is no exception. The largest North American companies produce the most gold and operate globally, and therefore should have the highest potential to believe they can obtain valuable information with respect to the future gold production and hence, the gold price. Therefore, all else equal, we expect larger firms to speculate more than smaller firms.

An implied assumption in the foregoing discussion is that some firms and market participants believe that gold prices are at least partly predictable. Evidence in Pierdzioch, Risse and Rohloff (2014) suggests that gold markets are efficient and thus, gold prices are largely unpredictable. Alternatively, Brown, Crabb and Haushalter (2006) provide some evidence that markets believe large gold mining firms possess an information advantage about future gold prices. For example, they document that the price of gold shot up about $8 \%$ upon the announcement that Placer Dome, a large gold producer in our sample, was cutting the extent of its hedging. Similarly, gold prices dropped almost 3\% when Barrick Gold, another large gold mining firm, announced they would maintain their policy to hedge a large portion of their expected production.

However, selective hedging exposes a firm to new risks because the firm's private information may be noisy or turn out to be incorrect. Stulz (1996) therefore predicts that only firms with sufficient financial strength will engage in selective hedging to benefit from a 
perceived information advantage. Financially less stable firms should refrain from incorporating their market views in order not to jeopardize their core businesses. This argument suggests that financially stronger firms will speculate more than financially weaker firms.

In contrast, Stulz (1996) further notes that wealth transfer motives, as in Jensen and Meckling (1976) and Myers (1977), would provide managers of financially distressed firms with an incentive to speculate regardless of whether or not they have an information advantage. In a similar vein, Campbell and Kracaw (1999) argue that financially constrained firms have an incentive to increase risk exposure to potentially supplement their internal cash reserves and thereby overcome their financial constraints. These arguments imply that financially constrained or distressed firms would speculate more than financially secure firms. Using our unique data, we empirically examine the relationship between financial constraints/distress and selective hedging to determine which of these two opposing hypotheses prevails in practice.

If selective hedging is motivated by asset substitution considerations, this would naturally raise the question of how selective hedging is related to corporate governance. For example, is corporate speculation positively related to less monitoring by the board? While valuemaximizing corporate governance structures can vary across firms as pointed out by Coles, Lemmon and Wang (2009), identifying any systematic relationships that may exist between speculation and governance will be informative.

Compensation structures may also affect a manager's willingness to take speculative gambles. Tufano (1996) and Bakke, Mahmudi, Fernando and Salas (2015) show that stock options reduce the likelihood that managers will hedge a firm's risk exposure. By induction and as argued by Géczy, Minton and Schrand (2007), stock options may cause some managers (especially those with large stock option portfolios) to become more risk tolerant and engage in 
explicit market timing activities that further increase stock price volatility. ${ }^{6}$ Therefore, we expect to find a positive relationship between speculation and the sensitivity of executives' compensation packages to their firm's stock price volatility.

\section{Data and methodology}

We study the derivatives transactions of a sample of 92 North American gold mining firms. The derivatives data is from the Gold and Silver Hedge Outlook, reported by firms on a quarterly proprietary industry survey conducted by Ted Reeve, an analyst at Scotia McLeod, from 1989 to 1999 . Unfortunately, this data collection was discontinued in 1999, which limits our study to the 1989-1999 period. ${ }^{7}$ The firms included in the dataset represent the majority of North American firms in the gold mining industry during this period. Firms that are not included tend to be small or privately held corporations. The gold industry is not vertically integrated, which means that their profits are mainly driven by the world market price of gold. Any information advantage about future gold prices is driven by their knowledge and control over future production (and thus, their global impact on the supply of gold). ${ }^{8}$

The Scotia McLeod dataset contains detailed quarterly information on all outstanding gold derivatives positions, i.e., the type of instrument, the size and direction of the position, average delivery prices and maturities for each instrument type, and the future expected gold production. There are a total of 2,541 firm-quarter observations of which 1,450 firm-quarters

\footnotetext{
${ }^{6}$ Based on the survey data collected by Bodnar, Hayt and Marston (1998), Géczy, Minton and Schrand (2007) find that the sensitivity of CFO compensation to stock returns (delta) is positively associated with the probability of actively taking positions, while the sensitivity of CEO compensation to stock returns is negatively related to speculation.

${ }^{7}$ To our knowledge, this is still the best available data set to systematically study corporate speculation with derivatives. Tufano (1996) studies 48 gold mining firms using quarterly data between 1991 and 1993 from the Ted Reeve dataset while Brown, Crabb and Haushalter (2006) study 44 gold mining firms using quarterly data between 1993 and 1998 from the same dataset. GFMS gold surveys provide more recent data on gold derivative holdings, but they no longer provide necessary expected production figures. Nonetheless, in unreported analysis we verify that our results continue to hold in the 2002-2011 period.

${ }^{8}$ We thank Fergal O'Connor (discussant at the Infiniti conference) for suggesting that we clarify this point.
} 
represent non-zero hedging portfolios. Tufano (1996) and Adam and Fernando (2006) provide further details about this data set.

Following Tufano (1996), we measure the extent of derivatives usage by a hedge ratio for each firm $i$ and time $t\left(h_{i t}^{p}\right)$ that is defined as follows:

$$
\text { Total hedge ratio }(\text { production })=\frac{- \text { Portfolio delta }(1-3 \text { year contracts })}{\text { Expected production }(1-3 \text { year ahead })}
$$

The portfolio delta is the amount of gold that the firm has effectively sold short, computed as the sum of the deltas of all of a firm's gold derivatives positions (in ounces of gold). ${ }^{9}$ Expected production is a firm's expected gold production over the next three years. Thus, this hedge ratio represents the fraction of gold production over the next three years that has been hedged.

Since some variation in the production-based hedge ratio may be caused by firms revising their expectations about their future gold production, we also calculate an alternate hedge ratio that reflects the fraction of a firm's total gold reserves that has been hedged, as in Jin and Jorion (2006). This ratio $\left(h_{i t}^{r}\right)$ is defined as follows:

$$
\text { Total hedge ratio }(\text { reserves })=\frac{- \text { Portfolio delta }(1-3 \text { year contracts })}{\text { Total gold reserves }}
$$

Gold reserves in ounces of gold are collected manually from firms' financial statements.

Following Haushalter (2000) and Adam and Fernando (2006), our methodology for measuring selective hedging explicitly accounts for the fact that hedging involves two sequential

\footnotetext{
${ }^{9}$ The dataset includes derivatives contracts with maturities of up to five years. However, since only a few firms use four and five year hedges - the average contract maturity is 1.5 years - we focus our attention on derivatives contracts that mature within three years. Including four and five year maturities does not change any of our conclusions. The results are available from the authors upon request.
} 
decisions: (a) to hedge or not to hedge; and (b) conditional on the decision to hedge, how much to hedge. We use a Heckman (1979) two-step model to reflect this two-stage decision process and control for any selection bias associated with estimating the speculation of firms that hedge. In the first stage, we estimate a probit regression to model the likelihood that a firm hedges. We calculate an Inverse Mills ratio from the first stage results, which we include in the second stage regression that models the extent to which firms hedge their gold production. ${ }^{10}$ As in Adam and Fernando (2006), this procedure gives us predicted hedge ratios $\left(\hat{h}_{i t}\right)$ for each firm $i$ and time $t$. Next, we measure the extent of selective hedging by the yearly standard deviation of the quarterly residuals $\left(e_{i t}\right)$ from the second step regression of the Heckman two-step model:

$$
\begin{gathered}
\text { Total speculation }(\text { production })_{i}=\sqrt{\frac{1}{4} \sum_{t=1}^{4}\left(e_{i t}^{p}\right)^{2}}=\sqrt{\frac{1}{4} \sum_{t=1}^{4}\left(h_{i t}^{p}-\hat{h}_{i t}^{p}\right)^{2}} \\
\text { Total speculation }(\text { reserves })_{i}=\sqrt{\frac{1}{4} \sum_{t=1}^{4}\left(e_{i t}^{r}\right)^{2}}=\sqrt{\frac{1}{4} \sum_{t=1}^{4}\left(h_{i t}^{r}-\hat{h}_{i t}^{r}\right)^{2}}
\end{gathered}
$$

Adam and Fernando (2006) measure the extent of speculation by the deviation of the actual hedge ratio from a predicted hedge ratio, i.e., a hedge ratio derived from a pure hedging paradigm, using five different methods, including the two methods we use here. They find that the five methods yield broadly similar results.

Brown, Crabb and Haushalter (2006) use the standard deviation of quarterly hedge ratios to measure the extent of speculation. We also follow their methodology and calculate two further measure of speculation, which are defined as follows:

$$
\text { Total speculation }^{p}(\text { robustness })_{i}=\sqrt{\frac{1}{4} \sum_{t=1}^{4}\left(h_{i t}^{p}-\bar{h}_{i}^{p}\right)^{2}}
$$

\footnotetext{
${ }^{10} \mathrm{We}$ also include quarterly dummy variables in the second stage to account for seasonality in hedging.
} 


$$
\text { Total speculation }^{r}(\text { robustness })_{i}=\sqrt{\frac{1}{4} \sum_{t=1}^{4}\left(h_{i t}^{r}-\bar{h}_{i}^{r}\right)^{2}}
$$

We obtain financial data from Compustat or from a manual search of firms' financial statements if a firm is not covered by Compustat. Stock prices are obtained from CRSP. This data is used to calculate measures of firm size, market-to-book ratio of assets, leverage, liquidity, dividend policy, Altman's (1968) Z-score, and Ohlson's (1980) O-score. All variable definitions are provided in Appendix I. Table 1 provides summary statistics of our sample.

[Place Table 1 about here]

Altman (1968) shows that firms with Z-scores less than 1.81 are associated with a "high" probability of distress, whereas firms with Z-scores above 2.99 are in the "safe zone." The descriptive statistics in Panel A of Table 1 show that while the mean and median Z-scores in our sample are 2.54 and 2.46 , respectively, the $10^{\text {th }}$ and $90^{\text {th }}$ percentiles are 0 and $5 .{ }^{11}$ Thus, despite the industry focus, the firms in our sample exhibit a wide range of probabilities of bankruptcy with approximately a third having Z-scores below 1.81. Our O-score summary statistics are quite similar to those reported by Dichev (1998), who uses the universe of post-1980 industrial firms in his study. For example, the mean and standard deviation of O-scores in our sample are -1.41 and 3.69 respectively, compared to -1.44 and 3.19 in Dichev (1998). ${ }^{12}$ Leverage averages $42 \%$ in our sample, and $43 \%$ of our firm-year observations are for dividend payers. We observe considerable variation in firm characteristics across our sample firms.

The descriptive statistics in Panel B of Table 1 show that $74 \%$ of our sample firms are hedgers. Among hedgers, an average of $44 \%$ of their expected gold production is sold forward

\footnotetext{
${ }^{11} \mathrm{We}$ winsorize the Z-scores at zero on the left and five on the right to prevent our results from being influenced by extreme values.

${ }^{12}$ As with the Z-scores, we truncate O-scores at the $1 \%$ level to avoid the possibility of extreme observations driving our results.
} 
over a three-year horizon. For this same sample of hedgers, average hedge ratios decline from $49 \%$ for one-year maturities to $21 \%$ for three-year maturities, indicating that most of the derivatives activity takes place in shorter maturity contracts.

We also collect data on several corporate governance measures that have been used in the literature. We collect data from proxy statements about the size of the board of directors, ${ }^{13}$ the percentage of outsiders on the board of directors, ${ }^{14}$ board classification (a dummy variable equal to one if the board is staggered and zero otherwise), ${ }^{15}$ the tenure of CEOs, ${ }^{16}$ and institutional ownership in the firm. ${ }^{17}$ Outside directors are directors who are neither executives nor individuals who are likely to have a business relationship with the firm, such as lawyers or bankers. We identify CEOs who also hold the position of chairman of the board. ${ }^{18}$

The descriptive statistics in Panel $\mathrm{C}$ of Table 1 show that board sizes mostly vary between 6 and 13 board members, with a median of 8 directors. Of these, $71 \%$ are outside directors. About $29 \%$ of the boards in the sample are staggered, and about half of the CEOs also hold the title of chairman of the board. Institutions own on average $21 \%$ of the equity of our sample firms.

Finally, we gather compensation data from ExecuComp or through manual collection from proxy statements if the firm is not covered by ExecuComp. We also obtain the stock and option holdings for CEOs and CFOs. We then estimate the sensitivities of stock and option holdings to changes in stock price level (delta) and volatility (vega) following the methodology of Core and Guay (2002). We use the end of year stock price from Compustat as the underlying

\footnotetext{
${ }^{13}$ See, for example, Jensen (1993), Yermack (1996), Coles, Daniel and Naveen (2008), and Linck, Netter and Yang (2008).

${ }^{14}$ See, for example, Weisbach (1988), Brickley, Coles, and Terry (1994), and Coles, Daniel and Naveen (2006).

${ }^{15}$ See, for example, Faleye (2007).

${ }^{16}$ See, for example, Hermalin and Weisbach (1988), and Ryan and Wiggins (2004).

${ }^{17}$ See, for example, Shleifer and Vishny (1986), Carleton, Nelson and Weisbach (1998), Gillan and Starks (2000), and Hartzell and Starks (2003).

${ }^{18}$ See, for example, Fama and Jensen (1983), Jensen (1993), and Brickley, Coles, and Jarrell (1997).
} 
stock price in the Black-Scholes options pricing formula. We obtain any cash dividends paid by the firm from Compustat. The risk-free interest rate is the yield on the Treasury bond whose maturity is closest to the maturity of the stock option. We compute stock return volatility from weekly adjusted stock returns obtained from CRSP and Datastream. We calculate the delta of each executive's compensation as the sum of the deltas of all outstanding options plus the delta of the executive's shareholdings. We calculate the vega of the executive's compensation as the sum of the vegas of all option holdings of the executive. Following Coles, Daniel and Naveen (2006), we assume the vega of shareholdings to be zero. Appendix I provides further details on the calculation of delta and vega. We use lagged compensation data in all our regressions.

\subsection{Estimation of speculation measures}

To compute our measures of speculation, we must first model the magnitude of hedging by firms. Since the decision to use derivatives is not random, it is possible that our hedging sample may be subject to sample selection bias. To control for this potential selection bias, we estimate Heckman two-step selection models. The first step models the decision to use derivatives using a standard probit model conditional on several explanatory variables (equation 7 below). We use several explanatory variables ( $\mathrm{Z}$ in equation 7 ) that have been identified in the prior literature as determinants of hedging. These variables include firm size, the market-to-book ratio of assets, dividend policy, liquidity and leverage. ${ }^{19}$ Here, $\gamma$ represents the estimated coefficients in the probit regression.

$$
\operatorname{Prob}(\text { Hedging }=1 \mid Z)=\phi(\gamma Z)
$$

The second step models the magnitude of hedging via OLS against firm characteristics, using the Inverse Mills Ratio ( $\lambda$ below) as an additional regressor to correct for any sample

\footnotetext{
${ }^{19}$ See, for example, Tufano (1996) and Haushalter (2000).
} 
selection bias (equation 8 below). ${ }^{20}$ We also add quarterly dummy variables to control for any predictable intra-year time series variation in hedge ratios. The sample in the second step is limited to derivatives users only.

$$
E[\text { Hedge ratio } \mid \text { Hedging }=1]=\beta X+\theta \lambda
$$

Results of the Heckman two-step regressions are presented in Table 2. Consistent with prior studies we observe a strong positive relation between the likelihood of using derivatives and firm size (statistically significant at the $1 \%$ level for all model specifications). ${ }^{21}$ Furthermore, we find negative relations between the market-to-book ratio and the decision to use derivatives. The market-to-book ratio is widely used as a proxy for growth opportunities. In the mining industry it is likely to proxy for the magnitude of a firm's gold price exposure. Firms with fewer growth opportunities have more developed mines in operation and thus larger gold price exposures stemming from future gold sales than firms with more growth opportunities. We also find that the decision to use derivatives is negatively correlated with both corporate liquidity and whether or not a firm pays dividends. Holding liquidity can be seen as a substitute for hedging, which would explain the negative correlation between the decision to use derivatives and the quick ratio. Overall, these results are consistent with Tufano (1996).

[Place Table 2 about here]

Next, we use the residuals from the second stage regression to calculate the total speculation measures according to equations (3) and (4). Panel B of Table 1 shows descriptive statistics of the two speculation measures. These measures of speculation are the dependent

\footnotetext{
${ }^{20} \mathrm{We}$ use robust standard errors in the second step of the two-step procedure.

${ }^{21}$ See, for example, Tufano (1996), Bodnar, Hayt and Marston (1998), Haushalter (2000) and Adam and Fernando (2006).
} 
variables in our main tests as expressed in equation (9) below where $\mathrm{Y}$ are firm and executive characteristics and $\partial$ is a vector of parameter estimates.

$$
E[\text { Speculation } \mid \text { Hedging }=1]=\partial Y
$$

\section{Empirical results}

We examine how selective hedging is related to firm size, the probability of bankruptcy, and a number of corporate governance variables. After obtaining our primary speculation measures from the Heckman two-step regressions described in the previous section, we estimate our regressions using OLS, controlling for firm-level clustering in all our tests to avoid biased standard errors (Petersen, 2009). We carry out robustness checks using alternate speculation measures and alternate measures of a firm's potential information advantage. We conclude by examining the possibility that selective hedging may be related to managerial compensation.

\subsection{Speculation, firm size and the probability of bankruptcy}

Table 3 presents the results on how speculation is related to firm characteristics, including its corporate governance characteristics. In this subsection, we focus specifically on how firm size, as a proxy for inside information about the gold market, and Altman's Z-score and Ohlson's (1980) O-score, as measures of the probability of bankruptcy, are related to the extent of speculation. The results in Table 3 provide strong evidence that smaller firms speculate more than larger firms, with the relation between selective hedging and firm size being statistically significant in all eight specifications. For example, an increase in firm size by one standard deviation from the mean is associated with a decrease in total speculation (reserves) by around 0.0191. We obtain substantively similar results for our other speculation measures. Given

that the mean value of total speculation (reserves) is only 0.03 , this represents a reduction of 
$64 \%$. This finding is especially remarkable in light of the fact that it is typically the larger firms that are more likely to hedge and hedge more of their gold production than smaller firms.

[Place Table 3 about here]

As noted in Section 2, the theoretical relation between selective hedging and the likelihood of financial distress is ambiguous. Stulz (1996) highlights the need for firms that engage in selective hedging to have the financial strength to bear the additional risk of acting on their market views. On the other hand, Stulz (1996) and Campbell and Kracaw (1999) provide different reasons as to why financially distressed firms could have more incentives to speculate than financially secure firms. To test for this potential convexity, we allow for the relationship between speculation and Z-scores/O-scores to be non-linear by including the square of Zscores/O-scores.

Our tests support the argument that speculation is positively related to the likelihood of financial distress. The relationship between speculation and Z-score is negative and statistically significant at the 5\% level or better in all our specifications. Since the Z-score decreases with the probability of bankruptcy, this finding confirms that firms with a higher probability of bankruptcy speculate more. We obtain consistent results using O-scores although the coefficients are statistically significant (at the 5\% level) only for one of our two speculation measures. Oscores increase with the probability of bankruptcy and we observe a positive significant coefficient between total speculation (production) and O-scores.

We also observe some evidence of convexity in the relationship when we use Z-scores to proxy for bankruptcy risk. The coefficient on the $\mathrm{Z}^{2}$ term is positive and statistically significant at the $5 \%$ level or better in all our specifications. In contrast, the coefficient on $\mathrm{O}^{2}$ does not have a consistent sign and has lower levels of statistical significance. Furthermore, the economic 
magnitude of the coefficient on the $Z^{2}$ term is small. This implies that we are estimating mostly the downward-sloping part of a quadratic relation rather than a symmetric U-shaped relation. For example, total speculation measured using either production or reserves is minimized at $\mathrm{Z}$ scores that are slightly above 3.5 . In both cases, approximately $70 \%$ of the corresponding sample firms have $\mathrm{Z}$ scores below this value. Taking account of the convexity, a decrease in the Z-score from 2 to 1 is associated with an increase in total speculation (reserves) by 0.021 , which represents an increase of $70 \%$ relative to the mean value of total speculation. In contrast, an increase in the Zscore from 4 to 5 is associated with an increase in total speculation (reserves) of 0.0037 , an increase of only $12 \%$ relative to the mean. Therefore, while decreases in the Z-score for low values of $\mathrm{Z}$ lead to economically significant increases in speculation, the increases in speculation associated with $\mathrm{Z}$-score increases for high values of $\mathrm{Z}$ are considerably more modest. A similarly stark asymmetry between the two sides of the U-shape is observed when we use total speculation (production), which confirms that we are, indeed, estimating mostly the downward-sloping part of the quadratic relation. As a consequence of this convex relation, for firms facing higher probabilities of financial distress (roughly the bottom two-thirds of our sample ranked by Zscore) we find support for the arguments in Stulz (1996) and Campbell and Kracaw (1999) that financially distressed firms will speculate more than financially secure firms.

If financially distressed firms speculate more than financially secure firms, we would also expect to find that speculation causes higher stock return volatility, which would be consistent with the motive that drives these firms to speculate in the first place. We test for this possibility by examining how lagged changes in speculation are related to changes in stock return volatility after controlling for a variety of other determinants of stock return volatility. The results are reported in Table 4. The coefficient on the lagged speculation change is positive and statistically 
significant at the $5 \%$ level or better for total speculation (production), at the $1 \%$ level for 2-year speculation and at the $10 \%$ level for one of our total speculation (reserves) specifications. While the other coefficients are not statistically significant, these results provide considerable support for the notion that corporate speculation may be motivated at least in part by wealth transfer reasons or to overcome financial constraints. ${ }^{22}$

[Place Table 4 about here]

In summary, we find that larger firms are more likely to hedge than smaller firms, and hedge more of their production than smaller firms. These findings are consistent with prior studies, and may indicate that larger firms are more sophisticated and can commit greater financial resources and expertise to a risk management program than smaller firms. In contrast, we find that smaller firms speculate more than larger firms. This finding is puzzling because larger firms should be more likely to have or believe they have an information advantage about the gold market than smaller firms and therefore, if firms speculate based on superior information, we would expect to see a higher propensity to engage in selective hedging among larger firms. It is possible that smaller firms are more likely to erroneously believe that they have information the market does not have, when in fact they do not, which is consistent with the view stemming from Graham and Harvey (2001) that smaller firms are financially less sophisticated than larger firms. Overconfident managers are examples of managers who may erroneously believe they have an ability to predict gold prices, As Malmendier and Tate (2005) show, these managers tend to overinvest and underperform.

Our findings are also consistent with the argument in Campbell and Kracaw (1999). Smaller firms are more constrained in raising external capital due to asymmetric information,

\footnotetext{
${ }^{22} \mathrm{We}$ also have examined the relation between Tobin's Q and selective hedging (see, for example, Allayannis and Weston (2001)), and find that it is either insignificant or negative depending on model specification. The results are not reported but are available on request.
} 
and may engage in selective hedging in the hope of supplementing their smaller internal resources. Additionally, our finding that among financially weaker firms, those that have a higher probability of bankruptcy speculate more lends support to the Stulz (1996) agencytheoretic notion that shareholders of firms close to bankruptcy may have incentives to speculate at the cost of bondholders.

\subsection{Selective hedging and corporate governance characteristics}

Our findings that selective hedging increases stock return volatility taken together with the findings in Adam and Fernando (2006) and Brown, Crabb, and Haushalter (2006), that selective hedging does not increase shareholder returns, also raise the question of how selective hedging is related to corporate governance. Is there a systematic association between specific governance characteristics and an activity that seemingly creates no value for shareholders? Unfortunately, the availability of corporate governance data for our sample of firms is considerably limited and restricts the extent of analysis we can carry out to address this issue.

Table 3 also presents the results of our analysis of how selective hedging is related to (a) several board characteristics, (b) CEO tenure, and (c) institutional ownership. While some of our results are relatively weak and while the normative assessment of our results are subject to the caution advanced by Coles, Lemmon and Wang (2009) about the pitfalls of interpreting performance on structure models, we highlight a few noteworthy relationships between selective hedging and corporate governance measures. The coefficient for board size is positive and statistically significant at the $5 \%$ level or better for both measures of total speculation. These results suggest that firms with larger boards speculate more than firms with smaller boards. We also find that the coefficient for the staggered board dummy is negative and significant at the 5\% level for total speculation in model I. This finding suggests that firms with staggered boards 
speculate less. Board independence and CEO duality do not seem to affect speculation in our study. The coefficient for CEO tenure, while negative in all four specifications, is only statistically significant in models III and IV.

We repeat our tests by including firm-level fixed effects to allow for the possibility that our previous results may be driven by omitted variables. We do so by including firm-level fixed effects in the second step of the Heckman two-step procedure before we estimate the residuals with which we calculate our measure of speculation. We then obtain these new residuals and reestimate speculation as before. We present the results of our analysis with this alternative measure of speculation in models V-VIII of Table 3. All our results are virtually unchanged when we add fixed effects to the second step of the Heckman two-step regression.

Overall, our results show that speculation is weakly related to a number of corporate governance measures. Among the strongest of these relationships is the finding that firms with larger boards speculate more than firms with smaller boards. In the absence of any evidence of a positive relation between speculation and shareholder value, these results also complement our earlier findings about the positive association between the likelihood of financial distress and corporate speculation, and suggest that the value-maximizing drivers of selective hedging postulated by Stulz (1996) are not at work in our sample of firms. Nonetheless, these results should be interpreted with caution due to their relatively low statistical significance.

\subsection{Robustness}

We perform additional empirical tests to further examine the robustness of the previously presented findings to the use of (a) alternate speculation measures and (b) alternate measures of a firm's potential information advantage. 
We first carry out robustness checks using our alternate measure of speculation. Following Brown, Crabb and Haushalter (2006), we use the standard deviation of quarterly hedge ratios to measure the extent of speculation. As before, we carry out the analysis using the Heckman (1979) two-step procedure except that unlike before, we directly model speculation in the second stage. ${ }^{23}$ We present the second step results in Table 5. The results are consistent with the results reported in Table 3. Speculation continues to be negatively related to firm size and $\mathrm{Z}$ score in most models. Speculation is weakly positively related to O-scores for total speculation (production). In addition, $\mathrm{Z}^{2}$ is positive and statistically significant in all specifications. As in Table 3, board size is positively related to speculation in models II-IV (statistically significant at the $1 \%$ level). As before, board independence and CEO-chair duality are not significant. Our results are consistent with our finding in Table 3 that firms with larger boards speculate more than firms with smaller boards. The staggered board dummy is negative in model I. While institutional ownership was not significantly related to speculation in Table 3, with our alternate measure of speculation institutional ownership is negatively related to speculation at the 5\% level, providing weak evidence to suggest that institutions help monitor executives to reduce speculation.

[Place Table 5 about here]

We have argued that firm size is a reasonable proxy for a firm's information advantage because larger firms have better access to information through their more extensive market presence, and because they would also typically have more expertise and other resources to acquire any information they may need. In unreported work, we examine whether our previous findings are robust to the use of four alternate measures of a firm's potential information

\footnotetext{
${ }^{23}$ Because we calculate the standard deviation of hedge ratios before running the second step in the Heckman twostep procedure, we are left with significantly fewer observations for the second-step regression, which makes it impossible to include firm fixed effects in this specification.
} 
advantage -- a firm's annual gold production, gold reserves, firm age and CEO tenure. Since the information advantage in our case pertains to the future price of gold, and because some of the firms in our sample are also engaged in the mining of other metals and commodities, gold production and reserves have the potential to provide more precise measures of a firm's footprint in the gold market, albeit at the cost of diluting other drivers of information advantage such as management quality and other sources of in-house expertise, and access to external information resources. Similarly, it is conceivable that older firms have more in-house experience and expertise which can provide an information advantage, as can CEOs who have served longer in their positions. The results, which are available on request, are consistent with our previous conclusions using firm size as a proxy for information advantage.

Finally, although our dataset ends in 1999, we were able to obtain a different dataset from an online source for the period 2002-2011 (from surveys collected by the VM Group for Fortis Bank Nederland). ${ }^{24}$ Gold prices increased significantly during this period and firms significantly decreased their level of hedging. Although the 1989-1999 and 2002-2011 datasets are not fully consistent, we document (in unreported analysis) that our key results hold in the 2002-2011 period. Larger firms speculate less and more constrained firms speculate more.

\subsection{Selective hedging and managerial compensation}

In this section, we examine the possibility that selective hedging may be a rational managerial response to incentive compensation. As noted in Section 2, if selective hedging increases the volatility of a firm's stock, managers who hold a significant number of stock options may be more inclined to speculate than managers with few or no stock options because the value of options increases with volatility. If so, we would expect to find a positive relation between speculation and the sensitivity of executives' compensation packages to their firm's

\footnotetext{
${ }^{24}$ These surveys are posted online by GFMS gold surveys.
} 
stock price volatility. On the other hand, Adam and Fernando (2006) and Brown, Crabb and Haushalter (2006) show that firms do not earn economically significant cash flows on average from selective hedging, which implies that corporate speculation does not create shareholder value. If this is common knowledge among a firm's managers, we would expect corporate speculation to decrease with the sensitivity of managerial stock and option holdings to the firm's stock price.

We measure a manager's wealth sensitivity to stock price movements, which can result from holding stock as well as stock options, by the sum of the deltas of stock and option holdings of the CEO or the CFO. We measure the sensitivity of stock option holdings to changes in the stock price volatility by calculating the aggregate vega of the option holdings of the CEO or CFO.

The results for CEO and CFO compensation are presented in Table 6. None of the four compensation coefficients (CEO delta, CEO vega, CFO delta and CFO vega) are statistically significant in any of our specifications.

[Place Table 6 about here]

In unreported work, we have also examined the relation between executive compensation and selective hedging controlling only for firm size. In this case, some of the compensation coefficients are negative and statistically significant, suggesting that if at all, stock and option compensation deters executives from engaging in selective hedging. These results are available on request.

Our finding that speculation is unrelated to the vega of option holdings by either CEOs and CFOs provides no support for the view that stock option ownership could motivate managers to speculate in order to increase stock return volatility and thus increase the value of their stock 
options. Our finding that speculation does not increase with vega is especially significant in light of the result reported in Table 4 that speculation increases stock price volatility, and runs counter to the findings in recent studies by Burns and Kedia (2006) and Denis, Hanouna and Sarin (2006) that stock option compensation is positively related to the likelihood that managers will engage in strategies that potentially hurt shareholders. Burns and Kedia (2006) find that the sensitivity of the CEO's option portfolio to stock price is significantly positively related to the propensity to misreport earnings, while Denis, Hanouna and Sarin (2006) find that stock options increase the incentive for managers to engage in fraudulent activity. It is possible that their awareness that selective hedging does not create value, coupled with their own stakes in the firm, deter executives who own options and stock from engaging in speculation.

\section{Conclusions}

There is considerable evidence that firms use derivatives not only to hedge but also to speculate. We examine whether this practice of selective hedging is consistent with the two economic criteria stipulated by Stulz (1996) for this activity to create value: (a) possession of private information by firms; and (b) possession of sufficient financial strength to take the additional risk that selective hedging imposes. We also examine the alternative possibility that firms engage in selective hedging activities due to asset substitution motives.

We find a negative relation between selective hedging and firm size, implying that smaller firms speculate more than larger firms. This finding is the opposite of what we would expect to find if firms engaged in selective hedging based on a belief that they have an information advantage. Our finding of a positive relation between the extent of selective hedging and the probability of financial distress, and between selective hedging and stock return volatility lends support to the alternative explanation that selective hedging is largely driven by wealth 
transfer motives. We also find weak relationships between speculation and some measures of corporate governance but find no evidence to suggest that speculation is driven by managerial compensation, which is especially significant in light of our finding that stock return volatility is positively related to speculation. Nonetheless, our study does not rule out the remaining possibility for selective hedging highlighted by Stulz (1996) -- that managers hedge selectively because they erroneously believe that they can outperform the market. ${ }^{25}$

Our findings have significant normative implications. We find no support for any shareholder value-maximizing rationale for selective hedging, which is consistent with the evidence documented in prior studies and calls for increased scrutiny of firms that engage in this practice by shareholders, corporate boards, and regulators. This is especially the case for smaller firms in light of our finding that smaller firms and firms that are closer to financial distress are the firms that are more likely to engage in selective hedging. Our findings should be especially disconcerting since we also show that selective hedging increases riskiness. Additionally, our study does not factor in the cost of managerial time and other resources that selective hedging consumes.

\footnotetext{
${ }^{25}$ The findings of Aggarwal, Lucey, and O'Connor (2014) suggest that behavioral factors are widespread in the gold market.
} 


\section{Appendix I: Definition of variables}

This Appendix lists all the variables used in the paper, provides their definitions and explains how they are constructed. In addition to the 1989 to 1999 gold derivatives data set from the Gold and Silver Hedge Outlook by Ted Reeve/Scotia McLeod, the principal data sources are Compustat, CRSP, ExecuComp, firms' annual reports and 10-K forms. Market data is obtained from Datastream.

Altman's (1968) Z-score: Defined as: $Z=1.20 * X_{1}+1.40 * X_{2}+3.30 * X_{3}+0.60 * X_{4}+0.999 * X_{5}$

where $X_{1}=$ working capital (current assets - current liabilities)/total assets; $X_{2}=$ retained earnings/total assets; $X_{3}=$ earnings before interest and taxes/total assets; $X_{4}=$ market value of equity/ book value of total debt; and $X_{5}=$ sales/total assets.

Board size: The number of individuals on the board of directors.

CEO/CFO compensation delta and vega: CEO/CFO (aggregate) compensation delta is the change in the dollar value of the executive's wealth derived from ownership of stock and stock options in the firm when the firm's stock price changes by one percent. CEO/CFO (aggregate) compensation vega is the change in the dollar value of the executive's wealth derived from ownership of stock and stock options in the firm when the annualized standard deviation of the firm's stock price changes by 0.01 . We calculate the (aggregate) delta of the executive's compensation as the sum of the deltas of the options holdings and the delta of the stock holdings. We obtain the (aggregate) vega of the executive's compensation as the sum of the vegas of the executive's options holdings. Following Coles, Daniel and Naveen (2006) we disregard the vega of stock holdings. The delta and vega of options holdings are calculated based on the methodology in Guay (1999) and Core and Guay (2002). ${ }^{26}$

The deltas of stock and options holdings are given by:

$$
\text { Delta }(\text { stock holdings })=0.01 * S * \text { number of shares owned }
$$

\footnotetext{
${ }^{26}$ Following the convention in previous studies, while all the delta and vega measures we use in our analysis are aggregates over the executive's entire holdings in the firm, we omit using the qualifier "aggregate" when referring to compensation deltas and vegas elsewhere in the paper.
} 
Delta (options holdings) $=0.01 * e^{-d T} N(Z) S *$ number of options owned

where $Z=\left(\ln (S / X)+T\left(r-d+\sigma^{2} / 2\right)\right) /\left(\sigma T^{0.5}\right)$

$S=$ underlying stock price

$X=$ option exercise price

$T=$ time to maturity of the option (number of years)

$r=\ln [1+$ risk-free interest rate $]$

$d=\ln [1+$ expected dividend rate on the stock $]$

$\sigma=$ annualized stock return volatility

$N=$ cumulative density function for normal distribution

The vega of options holdings is given by:

Vega (options holdings) $=0.01 * e^{-d T} N^{\prime}(Z) S T^{0.5} *$ number of options owned

where $N=$ probability density function for normal distribution

CEO-Chair duality: This dummy variable is equal to one if the CEO also has the title of chairman of the board.

CEO tenure: The number of years the executive has served as CEO of the firm.

Dividend dummy: Equals one if a firm paid cash dividends in the given year and is zero otherwise.

Firm size: The natural logarithm of the market value of assets. The market value of assets equals book value of assets minus book value of common stock plus market value of equity.

Hedging dummy: Equals one if a firm is hedging (using derivatives) in a specific time period and is zero otherwise. Total hedging dummy equals one if a firm uses derivatives with 1-3 years to maturity and equals zero otherwise. $x$-year hedging dummy equals one if a firm uses derivatives with $x$-year maturity and equals zero otherwise. 
Hedge ratio: The total hedge ratio is the fraction of the firm's expected gold production (or reserves) over the next three years that it has hedged, calculated as the ratio of the portfolio delta for derivatives contracts that mature within three years to expected production (in ounces of gold) over the same three-year time period. Correspondingly, $x$-year hedge ratio is the fraction of the $x$-year expected gold production hedged.

Institutional ownership: The percentage of the firm that is owned by institutions as reported in proxy statements.

Leverage: Calculated as the book value of long-term debt divided by the sum of book values of preferred stock, common equity, and long-term debt.

Market-to-book ratio of assets: Market value of assets divided by book value of assets. The market value of assets equals the book value of assets minus the book value of common stock plus market value of equity.

Ohlson's O score: Defined based on Ohlson (1980) as: $O=-1.32-0.407 \log$ (total assets / GNP price-level index) +6.03 (total liabilities / total assets) - 1.43 (working capital / total assets) +0.076 (current liabilities / current assets) - 1.72 ( 1 if total liabilities $>$ total assets, else 0$)-2.37$ (net income / total assets) - 1.83 (funds from operations/total liabilities) +0.285 (1 if net loss for last two years, else 0) - 0.521 (net income $_{t}-$ net income $\left.e_{t-1}\right) /\left(\mid\right.$ net income $_{t}|+|$ net income $\left._{t-1} \mid\right)$.

Outside director ratio: The percentage of outside directors in the board of directors. Outside directors are those directors who are not employees of the firm or of banks or law firms that provide services to the firm.

Portfolio delta: Portfolio delta is the amount of gold that the firm has effectively sold short over a specific time period, computed as the sum of the firm's individual derivatives positions (in ounces of gold) weighted by their respective deltas.

Production: Amount of gold produced by the firm during the year (in thousands of ounces).

Quick ratio: Measure of corporate liquidity defined by the ratio: (cash + cash equivalents + receivables) / current liabilities. 
Reserves: Proven reserves of gold (in thousands of ounces) owned by the firm at the end of the fiscal year.

Speculation: Speculation is the yearly standard deviation of quarterly hedge ratio residuals from a Heckman (1979) two-step regression. In the first step of the Heckman two-step regression, the dependent variable is a hedging dummy that is equal to one if the firm hedges during the year and zero otherwise. The dependent variable in the second stage is the proportion of expected production or reserves that is hedged. Total speculation (production) is based on the total hedge ratio (production) and total speculation (reserves) is based on the total hedge ratio (reserves). An alternate measure of speculation - the yearly standard deviation of the quarterly total hedge ratios - is used in robustness checks.

Staggered board dummy: A dummy variable equal to one if the firm has staggered elections for directors and zero otherwise. 


\section{References}

Adam, T.R., Fernando, C.S. 2006. Hedging, speculation, and shareholder value. Journal of Financial Economics 81, 283-309.

Aggarwal, R., Lucey, B.M., O’Connor, F., 2014. Rationality in precious metals forward markets: Evidence of behavioural deviations in the gold markets. Journal of Multinational Financial Management, 25-26, 110-130.

Allayannis, G., Weston, J.P., 2001. The use of foreign currency derivatives and firm market value. Review of Financial Studies 14, 243-276.

Altman, E. I., 1968. Financial ratios, discriminant analysis and the prediction of corporate bankruptcy. Journal of Finance 23, 589-609.

Bakke, T., Mahmudi, H., Fernando, C.S., Salas J.M. 2015. The causal effect of option pay on corporate risk management. Journal of Financial Economics, forthcoming.

Bessembinder, H., 1991. Forward contracts and firm value: Investment incentive and contracting effects, Journal of Financial and Quantitative Analysis 26 (4), 519-532

Bodnar, G. M., Hayt, G.S., Marston, R.C., 1998. Wharton survey of derivatives usage by U.S. non-financial firms. Financial Management 27(4), 70-91.

Brickley, J.A., Coles, J.L., Terry, R.L., 1994. Outside directors and the adoption of poison pills. Journal of Financial Economics 35, 371-390.

Brickley, J.A., Coles, J.L., Jarrell, G., 1997. Leadership structure: Separating the CEO and chairman of the board. Journal of Corporate Finance 3, 189-220.

Brown, G. W., Crabb, P.R., Haushalter, D., 2006. Are firms successful at selective hedging? Journal of Business 79, 2925-2949.

Burns, N., Kedia, S., 2006. The impact of performance-based compensation on misreporting. Journal of Financial Economics 79, 35-67.

Campbell, T. S., Kracaw, W.A., 1999. Optimal speculation in the presence of costly external financing. In "Corporate Risk: Strategies and Management," Gregory Brown and Donald Chew, editors, Risk Publications, London.

Carleton, W. T., Nelson, J.M., Weisbach, M.S., 1998. The influence of institutions on corporate governance through private negotiations: Evidence from TIAA-CREF. Journal of Finance 53, 1335-1362.

Chidambaran, N. K., Fernando, C.S., Spindt, P., 2001. Credit enhancement through financial engineering: Freeport McMoRan's gold-denominated depositary shares. Journal of Financial Economics 60, 487-528.

Coles, J. L., Lemmon, M. L., Wang, Y., 2009, The joint determinants of managerial ownership, board independence, and firm performance, Working Paper.

Coles, J. L., Daniel, N.D., Naveen, L., 2006. Managerial Incentives and risk taking. Journal of Financial Economics 79, 431-468.

Coles, J. L., Daniel, N.D., Naveen, L., 2008. Boards: Does one size fit all? Journal of Financial Economics 87, 329-356. 
Core, J., Guay, W., 2002. Estimating the value of employee stock option portfolios and their sensitivities to price and volatility. Journal of Accounting Research 40, 613-630.

DeMarzo, P. M., Duffie, D., 1995. Corporate incentives for hedging and hedge accounting. Review of Financial Studies 8, 743-772.

Denis, D. J., Hanouna, P., Sarin, A., 2006. Is there a dark side to incentive compensation? Journal of Corporate Finance 12, 467-488.

Dichev, I. D., 1998. Is the risk of bankruptcy a systematic risk? Journal of Finance 53, 11311147.

Faleye, O., 2007, Classified boards, firm value, and managerial entrenchment. Journal of Financial Economics, 83, 501-529.

Fama, E.F., Jensen, M., 1983. Separation of ownership and control. Journal of Law and Economics 26, 301-325.

Faulkender, M. W., 2005. Hedging or market timing? Selecting the interest rate exposure of corporate debt. Journal of Finance 60, 931-962.

Froot, K. A., Scharfstein, D. S., Stein, J. C. 1993. Risk management: Coordinating corporate investment and financing policies. Journal of Finance 48, 1629-1658.

Géczy, C., Minton, B. A., Schrand, C. M., 2007. Taking a view: Corporate speculation, governance, and compensation. Journal of Finance 62, 2405 - 2443.

Gillan, S., Starks, L. 2000. Corporate governance proposals and shareholder activism: The Role of institutional investors. Journal of Financial Economics 57, 275-305

Glaum, M., 2002. The determinants of selective exchange risk management - Evidence from german non-financial corporations. Journal of Applied Corporate Finance, 14, 108-121.

Graham, J. R., Harvey, C. R., 2001. The theory and practice of corporate finance: Evidence from the field. Journal of Financial Economics 60, 187-243.

Graham, J. R., Smith, C., 1999. Tax incentives to hedge. Journal of Finance 54, 2241-2262.

Graham, J. R., Rogers, D. A., 2002. Do firms hedge in response to tax incentives?, Journal of Finance 57, 815-839.

Guay, W. R., 1999. The sensitivity of CEO wealth to equity risk: An analysis of the magnitude and determinants. Journal of Financial Economics 53, 43-71.

Hartzell, J. C., Starks, L. T., 2003. Institutional investors and executive compensation. Journal of Finance 58, 2351-2374.

Haushalter, D., 2000. Financing policy, basis risk, and corporate hedging: evidence from oil and gas producers. Journal of Finance 55, 107-152.

Hermalin, B. E., Weisbach, M. S., 1988. The determinants of board composition. RAND Journal of Economics, 19, 589-606.

Jensen, M. C., Meckling, W. H., 1976. Theory of the firm: Managerial behavior, agency costs and ownership structure. Journal of Financial Economics 3, 305-360.

Jensen, M. C., 1993. The modern industrial-revolution, exit, and the failure of internal controlsystems. Journal of Finance 48, 831-880. 
Jin, Y., Jorion, P., 2006. Firm value and hedging: Evidence from U.S. oil and gas producers. Journal of Finance 61, 893-919.

Leland, H. E. 1998. Agency costs, risk management and capital structure. Journal of Finance 53 (4), 1213-1243.

Linck, J. S., Netter, J. M., Yang, T., 2008, The determinants of board structure, Journal of Financial Economics 87, 308-328.

Lucey, B.M., Larkin, C., O’Connor, F., 2014. Gold markets around the world - Who spills over what, to whom, when? Applied Economics Letters 21, 887-892.

Malmendier, U., Tate, G., 2005. CEO overconfidence and corporate investment. Journal of Finance 60, 2661-2700.

Myers, S. C., 1977. Determinants of corporate borrowing. Journal of Financial Economics 5, 147-175.

Ohlson, J. A., 1980. Financial ratios and the probabilistic prediction of bankruptcy. Journal of Accounting Research 18, 109-131.

Petersen, M. A., 2009. Estimating standard errors in finance panel data sets: Comparing approaches. Review of Financial Studies 22, 435-480.

Pierdzioch, C., Risse, M., Rohloff, S., 2014. On the efficiency of the gold market: Results of a real-time forecasting approach. International Review of Financial Analysis 32, 95-108.

Ryan, H. E., Wiggins, R. A., 2004. Who is in whose pocket? Director compensation, board independence, and barriers to effective monitoring. Journal of Financial Economics 73, 497-524.

Shleifer, A., Vishny, R. W., 1986. Large shareholders and corporate control. Journal of Political Economy 94, 461-488.

Smith, C., Stulz, R. M., 1985. The determinants of firms' hedging policies. Journal of Financial and Quantitative Analysis 20, 391-405.

Stulz, R. M., 1984. Optimal hedging policies. Journal of Financial and Quantitative Analysis 19, 127-140.

Stulz, R. M., 1990. Managerial discretion and optimal financing policies. Journal of Financial Economics 26, 3-27.

Stulz, R. M., 1996. Rethinking risk management. Journal of Applied Corporate Finance 9, 8-24.

Tufano, P., 1996. Who manages risk? An empirical examination of risk management practices in the gold mining industry. Journal of Finance 51, 1097-1137.

Tufano, P., 1998. The determinants of stock price exposure: Financial engineering and the gold mining industry. Journal of Finance 53, 1051-1052.

Weisbach, M. S., 1988. Outside directors and CEO turnover. Journal of Financial Economics 20, 431-460.

Yermack, D., 1996. Higher market valuation of companies with a small board of directors. Journal of Financial Economics 40, 185-211. 
Figure 1: Mean hedge ratios and gold prices

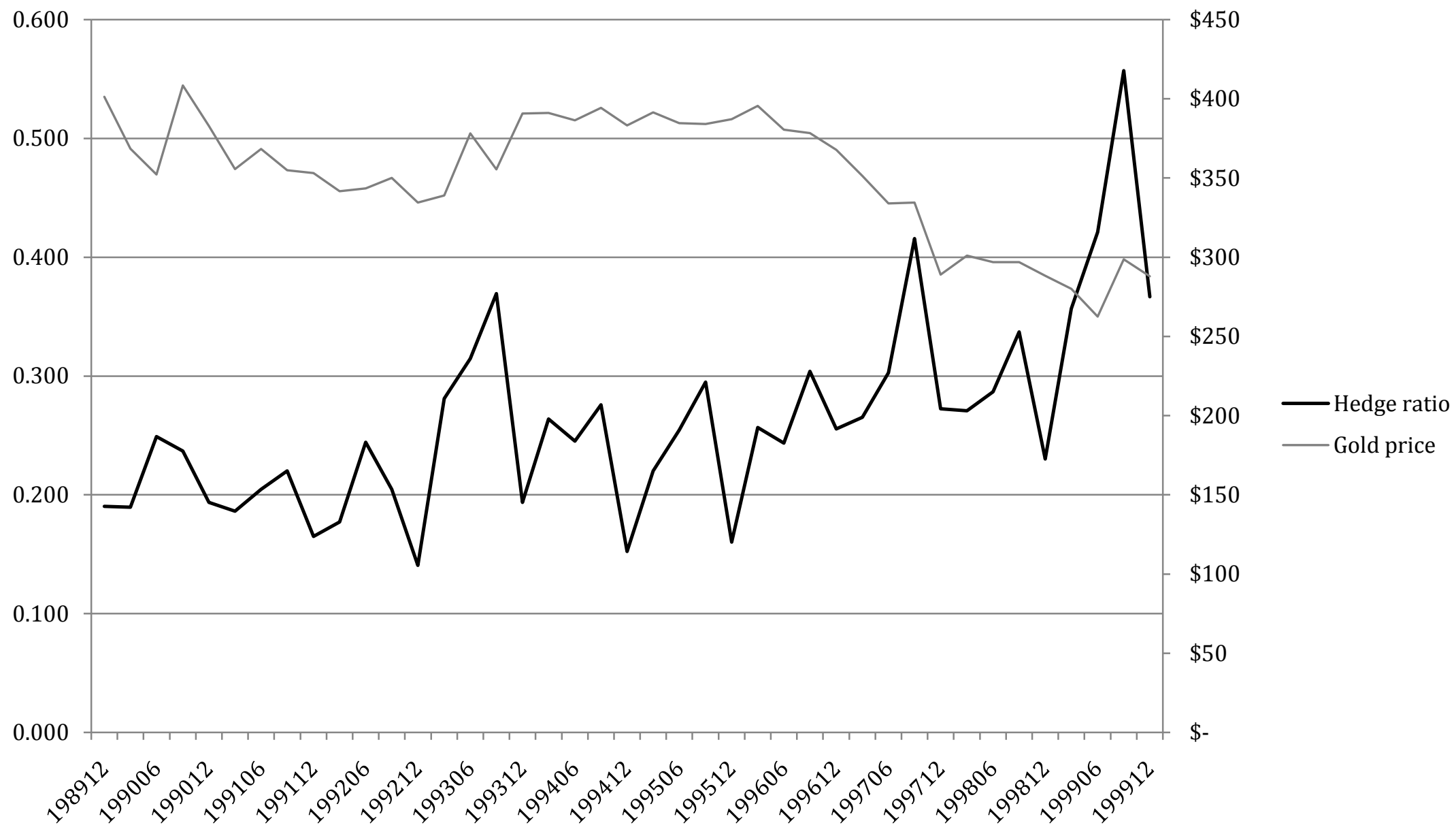


Figure R1: Mean hedge ratios and gold prices

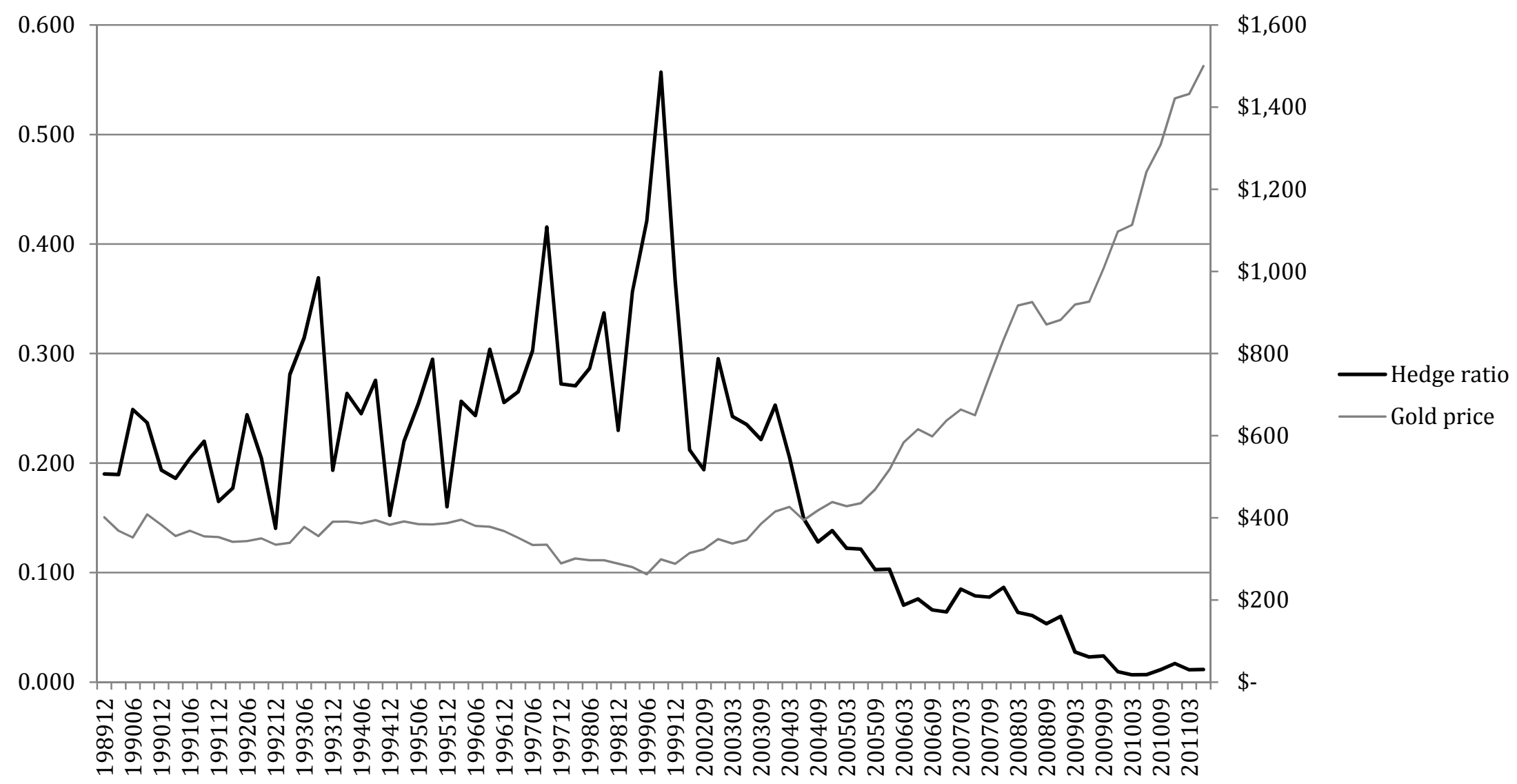


Table 1

Descriptive Statistics

This table presents descriptive statistics of firm characteristics, derivatives usage, CEO/CFO compensation and board characteristics for 92 North American gold mining companies between 1989 and 1999. Firm size is the log of the market value of assets in millions of US\$. Market-to-book ratio is the market value of assets divided by the book value of assets. Dividend dummy is a dummy variable that equals one if a firm paid cash dividends in year $t$ and zero otherwise. Quick ratio equals [(cash + cash equivalents + receivables) / current liabilities]. Leverage is the ratio of the book value of debt to the book value of preferred stock, common stock and long-term debt. Firm age is the number of years since the firm's incorporation. Z-scores and O-scores are calculated following Altman (1968) and Ohlson (1980), respectively. Total hedging dummy equals one if a firm uses derivatives in year t with 1-3 years to maturity and is equal to zero otherwise. Hedge ratio and predicted hedge ratio statistics are estimated only for hedgers. Total hedge ratio is the fraction of the future 3-year expected gold production (or reserves) hedged each quarter, calculated by dividing the 3 -year portfolio delta by the expected production over the next three years (or reserves). Total speculation is the yearly standard deviation of the quarterly residuals from a two-step Heckman regression of hedging on firm characteristics. Institutional ownership is the percentage of the firm owned by institutions as reported in proxy statements. CEO tenure is the tenure of the CEO in the firm. Board size is the number of members in the board of directors. Outsider director ratio is the fraction of outside members in the board of directors. Staggered dummy is equal to one if the board of directors is staggered and zero otherwise. CEO Chair duality is a dummy variable that equals one if the CEO is also the chairman of the board and zero otherwise. CEO and CFO compensation deltas and vegas are calculated as in Core and Guay (2002).

Mean Median Std. Dev $\begin{gathered}10 \text { th } \\ \text { Percentile }\end{gathered} \begin{gathered}90 \text { th } \\ \text { Percentile Obs. }\end{gathered}$

Panel A. Firm Characteristics

$\begin{array}{lcccccc}\text { Firm size } & 5.59 & 5.46 & 1.74 & 3.51 & 8.21 & 1993 \\ \text { Market-to-book ratio of assets } & 1.85 & 1.56 & 1.1 & 0.82 & 3.18 & 1993 \\ \text { Dividend dummy } & 0.43 & 0 & 0.5 & 0 & 1 & 1995 \\ \text { Quick Ratio } & 3.73 & 1.63 & 8.82 & 0.26 & 6.7 & 1966 \\ \text { Leverage } & 0.42 & 0.17 & 3.63 & 0 & 0.52 & 1976 \\ \text { Ohlson's O-score } & -1.41 & -1.76 & 3.69 & -4.42 & 2.45 & 1318 \\ \text { Altman's Z-score } & 2.54 & 2.46 & 1.84 & 0 & 5 & 1595\end{array}$

Panel B. Derivatives Usage Characteristics

\begin{tabular}{lcccccc} 
Total hedging dummy (quarterly) & 0.74 & 1 & 0.44 & 0 & 1 & 2274 \\
Total hedge ratio (production) & 0.44 & 0.34 & 0.39 & 0 & 0.98 & 615 \\
Total hedge ratio (reserves) (quarterly) & 0.08 & 0.05 & 0.11 & 0 & 0.2 & 1215 \\
Total speculation & 0.11 & 0.08 & 0.1 & 0.03 & 0.22 & 171 \\
Total speculation (reserves) & 0.03 & 0.01 & 0.05 & 0 & 0.06 & 293 \\
Panel C. Corporate Governance & & & & & & \\
\hline Board size & 8.63 & 8 & 2.81 & 6 & 13 & 1264 \\
Outsider director ratio & 0.71 & 0.714 & 0.14 & 0.5 & 0.89 & 1264 \\
Staggered board dummy & 0.29 & 0 & 0.45 & 0 & 1 & 1316 \\
CEO - Chair duality & 0.52 & 1 & 0.5 & 0 & 1 & 1306 \\
CEO tenure & 7.27 & 4 & 7.94 & 1 & 17 & 1450 \\
Institutional ownership & 0.21 & 0.1 & 0.27 & 0 & 0.71 & 1236 \\
Panel D. CEO/CFO Compensation Characteristics & & & & & \\
\hline Delta of CEO compensation $(\$ 000 \mathrm{~s})$ & 288.53 & 23.57 & 1204.23 & 3.75 & 305.34 & 1059 \\
Delta of CFO compensation $(\$ 000 \mathrm{~s})$ & 74.94 & 13.44 & 172.1 & 0.49 & 180.22 & 545 \\
Vega of CEO compensation $(\$ 000 \mathrm{~s})$ & 53.57 & 7.38 & 207.09 & 0.42 & 80.89 & 1135 \\
Vega of CFO compensation $(\$ 000 \mathrm{~s})$ & 8.94 & 3.04 & 20.89 & 0.02 & 18 & 792
\end{tabular}


Table 2

Heckman Two-Step Analysis of Hedging

This table presents regression results of a Heckman two-step selection model. The first step (model I) models the decision to use derivatives and the second step (models II and III) models hedge ratios as a function of firm characteristics. The dependent variables in the first step are total hedging dummies that equal one if a firm uses derivatives with 1-3 years to maturity and equal zero otherwise. The dependent variable in the second step is either the total hedge ratio, which is the fraction of the future 3-year expected gold production (or reserves) hedged each quarter, calculated by dividing the 3-year portfolio delta by the expected production over the next three years (or reserves). Firm size is the log of the market value of assets in millions of US\$. Market-to-book ratio is the market value of assets divided by the book value of assets. Dividend dummy is a dummy variable that equals one if a firm paid cash dividends in year $t$ and zero otherwise. Quick ratio equals [(cash + cash equivalents + receivables) / current liabilities]. Leverage is the ratio of the book value of debt to the book value of preferred stock, common stock and long-term debt. Figures in parentheses denote $t$-statistics and $*, * *$, and $* * *$ denote significance at the 10,5 , and $1 \%$ levels respectively.

\begin{tabular}{lc|cc} 
& $\begin{array}{c}\text { I } \\
\text { Total Hedging } \\
\text { Dummy }\end{array}$ & $\begin{array}{c}\text { II } \\
\text { Total Hedge Ratio } \\
\text { (production) }\end{array}$ & $\begin{array}{c}\text { III } \\
\text { Total Hedge Ratio } \\
\text { (reserves) }\end{array}$ \\
\hline Firm Size & $0.454^{* * *}$ & $0.0912^{*}$ & $0.0437^{* * *}$ \\
Market to book & -12.58 & -1.682 & -5.341 \\
& $-0.485^{* * *}$ & -0.0649 & $-0.0644 * * *$ \\
Dividend dummy & $(-9.606)$ & $(-0.914)$ & $(-5.230)$ \\
& $-0.250^{* *}$ & $-0.146 * * *$ & $-0.0484 * * *$ \\
Quick ratio & $(-2.104)$ & $(-3.614)$ & $(-4.822)$ \\
& $-0.00958^{*}$ & $-0.00878^{* * *}$ & $-0.00471^{* * *}$ \\
Leverage & $(-1.882)$ & $(-3.543)$ & $(-6.957)$ \\
& -0.151 & & \\
Inverse Mills ratio & $(-0.801)$ & & $0.262 * * *$ \\
& & 0.00797 & -4.408 \\
Intercept & & -0.0363 & $-0.122^{* * *}$ \\
Includes quarterly dummies & $(-7.287)$ & 0.0148 & $(-2.673)$ \\
Observations & No & -0.0455 & Yes \\
$\chi^{2}$ & 1041 & Yes & 1215 \\
Pr $>\chi^{2}$ & $\mathrm{NA}$ & 615 & 239.8 \\
& $\mathrm{NA}$ & 282.4 & $(<0.001)$
\end{tabular}


Table 3

Selective Hedging as a Function of Firm Characteristics, Board Characteristics, CEO Tenure and Institutional Ownership

This table presents the regression results of speculation as a function of firm characteristics, board characteristics, CEO tenure and institutional ownership. Total speculation is the yearly standard deviation of the quarterly residuals from a two-step Heckman regression of hedging on firm characteristics. Firm size is the log of the market value of assets in millions of US\$. Zscores and O-scores are calculated following Altman (1968) and Ohlson (1980), respectively. Institutional ownership is the percentage of the firm owned by institutions as reported in proxy statements. Staggered dummy is equal to one if the board of directors is staggered and zero otherwise. CEO-Chair duality is equal to one if the CEO is also the chairman of the board and zero otherwise. CEO tenure is the tenure of chief executive officers at their firms. Outside director ratio is the fraction of outsiders on the board of directors and board size is the number of directors on the board of directors. Figures in parentheses denote $t$-statistics estimated with standard errors adjusted for firm clustering following Petersen (2009) and *, **, and *** denote significance at the 10,5, and $1 \%$ levels respectively. The second stage in the Heckman two-step regression includes firm fixed effects for models V-VIII but not for models I-IV.

\begin{tabular}{|c|c|c|c|c|}
\hline Variable & $\begin{array}{c}\text { I } \\
\text { Total Specul }\end{array}$ & $\begin{array}{c}\text { II } \\
\text { (production) }\end{array}$ & $\begin{array}{c}\text { III } \\
\text { Total Specu }\end{array}$ & $\begin{array}{c}\text { IV } \\
\text { n (reserves) }\end{array}$ \\
\hline \multicolumn{5}{|c|}{ Panel A: Without firm fixed effects in second stage of Heckman regression } \\
\hline \multirow{2}{*}{ Firm size } & $-0.0232 * *$ & $-0.0290 *$ & $-0.0110 * * *$ & $-0.0159 * * *$ \\
\hline & $(-2.062)$ & $(-1.792)$ & $(-4.090)$ & $(-4.075)$ \\
\hline \multirow{2}{*}{ Z score } & $-0.0681 * * *$ & & $-0.0294 * *$ & \\
\hline & $(-3.121)$ & & $(-2.572)$ & \\
\hline \multirow{2}{*}{$Z$ score $^{2}$} & $0.00969 * * *$ & & $0.00413 * *$ & \\
\hline & -2.875 & & -2.236 & \\
\hline \multirow{2}{*}{ O score } & & $0.0211 * *$ & & $7.55 \mathrm{e}-05$ \\
\hline & & $(2.112)$ & & $(0.0394)$ \\
\hline \multirow[t]{2}{*}{ O score ${ }^{2}$} & & $0.00355^{*}$ & & $-0.000897 *$ \\
\hline & & $(1.970)$ & & $(-1.721)$ \\
\hline \multirow{2}{*}{ Board size } & $0.0153 * *$ & $0.0120 *$ & $0.00627 * * *$ & $0.00571 * * *$ \\
\hline & -2.659 & $(1.965)$ & -3.907 & $(3.188)$ \\
\hline \multirow{2}{*}{$\begin{array}{l}\text { Outside director } \\
\text { ratio }\end{array}$} & -0.0283 & 0.0404 & -0.0413 & -0.0341 \\
\hline & $(-0.415)$ & $(0.600)$ & $(-1.315)$ & $(-0.826)$ \\
\hline \multirow{2}{*}{ Staggered dummy } & $-0.0523 * *$ & $-0.0458 *$ & 0.00148 & -0.00391 \\
\hline & $(-2.137)$ & $(-1.751)$ & -0.153 & $(-0.453)$ \\
\hline CEO - Chair duality & $\begin{array}{l}-0.0239 \\
(-1.148)\end{array}$ & $\begin{array}{c}0.00421 \\
(0.173)\end{array}$ & $\begin{array}{c}-0.00594 \\
(-0.990)\end{array}$ & $\begin{array}{c}0.000343 \\
(0.0480)\end{array}$ \\
\hline \multirow{2}{*}{ CEO tenure } & 0.000577 & -0.000433 & -0.000519 & -0.000847 \\
\hline & -0.33 & $(-0.336)$ & $(-0.965)$ & $(-1.539)$ \\
\hline \multirow{2}{*}{$\begin{array}{l}\text { Institutional } \\
\text { ownership }\end{array}$} & -0.0168 & 0.0133 & -0.00237 & -0.000810 \\
\hline & $(-0.371)$ & $(0.289)$ & $(-0.206)$ & $(-0.0737)$ \\
\hline \multirow{2}{*}{ Intercept } & $0.251 * * *$ & $0.185^{* *}$ & $0.114 * * *$ & $0.116^{* * *}$ \\
\hline & -3.433 & $(2.432)$ & -3.824 & $(2.995)$ \\
\hline Observations & 117 & 119 & 206 & 202 \\
\hline R-squared & 0.285 & 0.189 & 0.200 & 0.157 \\
\hline
\end{tabular}


Table 3 -- continued

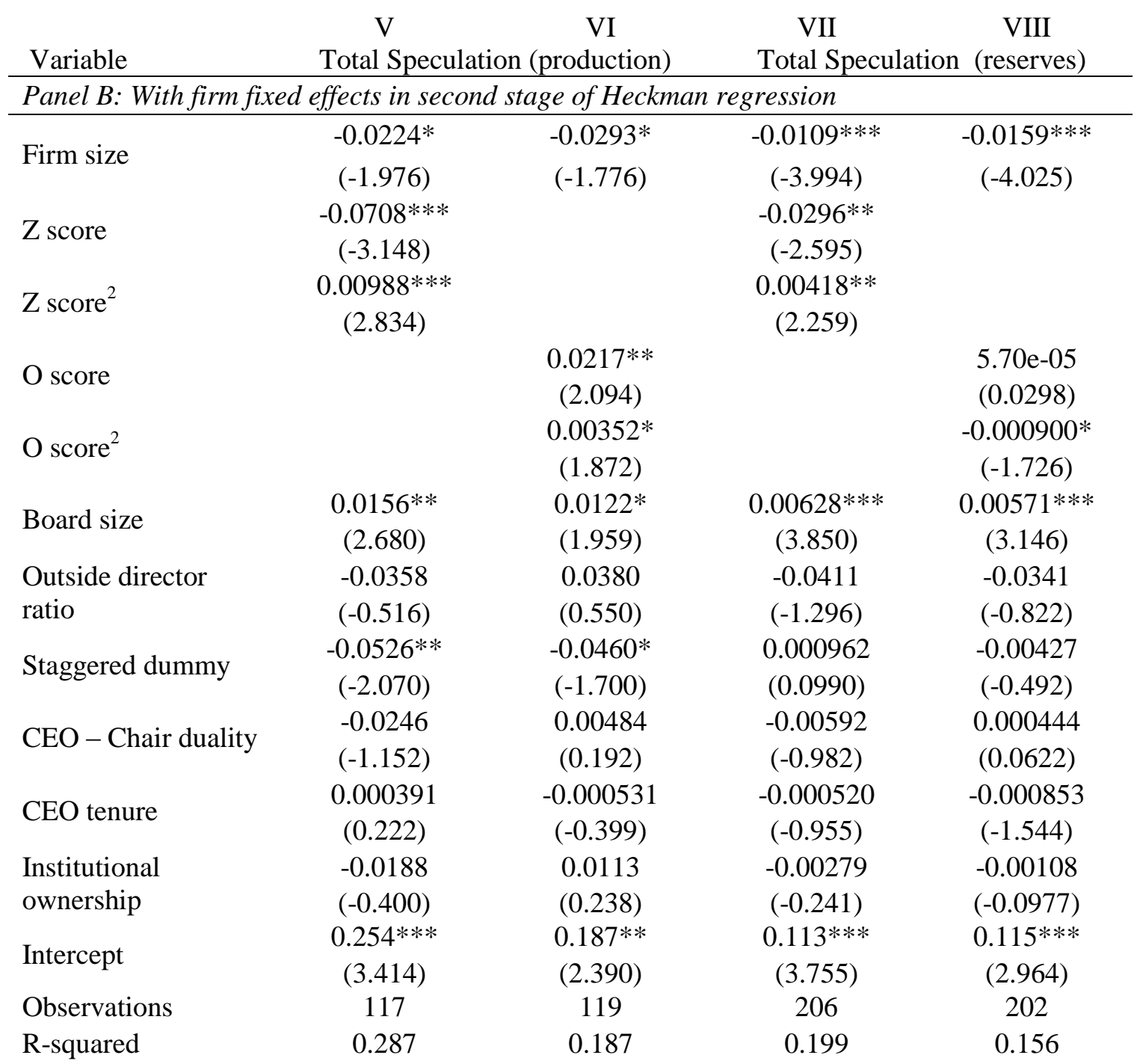


Table 4

Speculation and Stock Return Volatility

This table presents the regression results of lagged changes in speculation on changes in stock return volatility. The dependent variable in all regressions is the annualized weekly standard deviation of returns for the stock price during the year $\mathrm{t}$. Total speculation is the yearly standard deviation of the quarterly residuals from a two-step Heckman regression of hedging on firm characteristics. Firm size is the log of the market value of assets in millions of US\$. Market-tobook ratio is the market value of assets divided by the book value of assets. Quick ratio equals [(cash + cash equivalents + receivables) / current liabilities]. Leverage is the ratio of the book value of debt to the book value of preferred stock, common stock and long-term debt. Figures in parentheses denote $t$-statistics estimated with standard errors adjusted for firm clustering following Petersen (2009) and *,**, and *** denote significance at the 10,5 , and $1 \%$ levels respectively.

\begin{tabular}{|c|c|c|c|c|}
\hline \multirow[b]{2}{*}{ Variable } & I & II & III & IV \\
\hline & \multicolumn{4}{|c|}{ Changes in stock return volatility } \\
\hline DTotal speculation (production) $)_{t-1}$ & $\begin{array}{c}0.203 * * \\
(2.128)\end{array}$ & $\begin{array}{c}0.294 * * * \\
(3.260)\end{array}$ & & \\
\hline DTotal speculation (reserves) $)_{\mathrm{t}-1}$ & & & $\begin{array}{c}0.638 \\
(1.532)\end{array}$ & $\begin{array}{l}0.802 * \\
(2.014)\end{array}$ \\
\hline Dfirm size $_{t}$ & & $\begin{array}{l}-0.134 * * \\
(-2.240)\end{array}$ & & $\begin{array}{l}-0.0599 * \\
(-1.787)\end{array}$ \\
\hline Dquick $_{\mathrm{t}}$ & & $\begin{array}{c}-0.0105^{* *} \\
(-2.658)\end{array}$ & & $\begin{array}{c}-0.00677 * * * \\
(-2.934)\end{array}$ \\
\hline Dleverage $_{\mathrm{t}}$ & & $\begin{array}{l}-0.0285 \\
(-0.249)\end{array}$ & & $\begin{array}{c}0.00825 \\
(0.121)\end{array}$ \\
\hline Dmarket to book $\mathrm{t}_{\mathrm{t}}$ & & $\begin{array}{c}0.0830 * * \\
(2.267)\end{array}$ & & $\begin{array}{c}0.0676 * * * \\
(3.535)\end{array}$ \\
\hline Constant & $\begin{array}{c}0.0459 * * * \\
(4.607)\end{array}$ & $\begin{array}{c}0.0429 * * * \\
(4.073)\end{array}$ & $\begin{array}{c}0.0582 * * * \\
(6.238)\end{array}$ & $\begin{array}{c}0.0539 * * * \\
(5.483)\end{array}$ \\
\hline Observations & 91 & 86 & 188 & 178 \\
\hline R-squared & 0.026 & 0.207 & 0.021 & 0.127 \\
\hline
\end{tabular}


Table 5

Robustness Checks of Selective Hedging as a Function of Firm, Board and Executive Characteristics using Alternative Speculation Measures

This table presents the regression results of speculation as a function of firm characteristics, board characteristics, CEO tenure and institutional ownership. For this set of robustness checks, speculation is measured as the year by year standard deviation of quarterly hedge ratios. These standard deviations of hedge ratios are the dependent variable in the second step of the Heckman 2-step regressions. The first step models the decision to hedge as a function of firm characteristics. Firm size is the log of the market value of assets in millions of US\$. Z-scores and O-scores are calculated following Altman (1968) and Ohlson (1980), respectively. Institutional ownership is the percentage of the firm owned by institutions as reported in proxy statements. Staggered dummy is equal to one if the board of directors is staggered and zero otherwise. CEO-Chair duality is equal to one if the CEO is also the chairman of the board and zero otherwise. CEO tenure is the tenure of chief executive officers at their firms. Outside director ratio is the fraction of outsiders on the board of directors and board size is the number of directors on the board of directors. Figures in parentheses denote $t$-statistics estimated with standard errors adjusted for firm clustering following Petersen (2009) and *,**, and $* * *$ denote significance at the 10,5 , and $1 \%$ levels respectively.

\begin{tabular}{|c|c|c|c|c|}
\hline \multirow{3}{*}{$\begin{array}{l}\text { Variable } \\
\text { Firm size }\end{array}$} & \multicolumn{2}{|c|}{$\begin{array}{cc}\text { I } & \text { II } \\
\text { Total Speculation (production) }\end{array}$} & \multicolumn{2}{|c|}{$\begin{array}{cc}\text { IIII } & \text { IV } \\
\text { Total Speculation } & \text { (reserves) }\end{array}$} \\
\hline & -0.0157 & $-0.0283 * * *$ & $-0.00749 * * *$ & $-0.0154 * * *$ \\
\hline & $(-1.607)$ & $(-3.020)$ & $(-2.638)$ & $(-3.563)$ \\
\hline Z score & $\begin{array}{c}-0.0416 * * * \\
(-2.905)\end{array}$ & & $\begin{array}{c}-0.0323 * * * \\
(-2.758)\end{array}$ & \\
\hline$Z_{\text {score }}^{2}$ & $\begin{array}{c}0.00525 * * * \\
(2.636)\end{array}$ & & $\begin{array}{c}0.00424 * * \\
(2.241)\end{array}$ & \\
\hline O score & & $\begin{array}{c}0.0191 * \\
(1.977)\end{array}$ & & $\begin{array}{c}0.000252 \\
(0.148)\end{array}$ \\
\hline O score ${ }^{2}$ & & $\begin{array}{c}0.00202 \\
(1.100)\end{array}$ & & $\begin{array}{c}-0.000904^{*} \\
(-1.755)\end{array}$ \\
\hline Board size & $\begin{array}{l}0.0047 \\
(1.269)\end{array}$ & $\begin{array}{c}0.00817 * \\
(1.948)\end{array}$ & $\begin{array}{l}0.00575^{* * *} \\
\quad(3.04)\end{array}$ & $\begin{array}{l}0.00586^{* * * *} \\
\quad(2.957)\end{array}$ \\
\hline Outside director ratio & $\begin{array}{l}0.0803 \\
(1.429)\end{array}$ & $\begin{array}{l}0.0194 \\
(0.393)\end{array}$ & $\begin{array}{l}-0.0381 \\
(-1.160)\end{array}$ & $\begin{array}{l}-0.0321 \\
(-0.775)\end{array}$ \\
\hline Staggered dummy & $\begin{array}{c}-0.0433^{* *} \\
(-2.302)\end{array}$ & $\begin{array}{l}-0.0155 \\
(-1.030)\end{array}$ & $\begin{array}{c}-0.00153 \\
(-0.144)\end{array}$ & $\begin{array}{c}-0.00577 \\
(-0.777)\end{array}$ \\
\hline CEO - Chair duality & $\begin{array}{l}-0.00365 \\
(-0.209)\end{array}$ & $\begin{array}{l}-0.00103 \\
(-0.0701)\end{array}$ & $\begin{array}{l}-0.00326 \\
(-0.518)\end{array}$ & $\begin{array}{c}0.00101 \\
(0.146)\end{array}$ \\
\hline CEO tenure & $\begin{array}{c}-0.000721 \\
(-0.495)\end{array}$ & $\begin{array}{c}-0.00134 * \\
(-1.697)\end{array}$ & $\begin{array}{c}-0.000536 \\
(-0.821)\end{array}$ & $\begin{array}{c}-0.000874^{*} \\
(-1.748)\end{array}$ \\
\hline Institutional ownership & $\begin{array}{c}-0.0793^{* *} \\
(-1.995)\end{array}$ & $\begin{array}{c}0.00265 \\
(0.112)\end{array}$ & $\begin{array}{l}-0.00844 \\
(-0.662)\end{array}$ & $\begin{array}{l}-0.00289 \\
(-0.273)\end{array}$ \\
\hline Inverse Mills ratio & $\begin{array}{c}0.00438 \\
(0.133)\end{array}$ & $\begin{array}{l}-0.0206 \\
(-0.635)\end{array}$ & $\begin{array}{l}0.0311 \\
(1.219)\end{array}$ & $\begin{array}{c}0.00700 \\
(0.293)\end{array}$ \\
\hline Intercept & $\begin{array}{c}0.160^{* *} \\
(2.272)\end{array}$ & $\begin{array}{l}0.219 * * * \\
(3.544)\end{array}$ & $\begin{array}{l}0.0905 * * * \\
(3.298)\end{array}$ & $\begin{array}{c}0.107 * * * \\
(3.044)\end{array}$ \\
\hline Observations & 121 & 119 & 206 & 202 \\
\hline R-squared & 0.2219 & 0.294 & 0.1986 & 0.151 \\
\hline
\end{tabular}


Table 6

Selective Hedging and CEO/CFO Compensation Characteristics

This table presents the regression results of speculation as a function of CEO/CFO compensation characteristics. Total speculation is the yearly standard deviation of the quarterly residuals from a two-step Heckman regression of hedging on firm characteristics. Firm size is the $\log$ of the market value of assets in millions of US\$. CEO/CFO compensation deltas and vegas are calculated as in Core and Guay (2002). Figures in parentheses denote $t$-statistics estimated with standard errors adjusted for firm clustering following Petersen (2009) and *,**, and $* * *$ denote significance at the 10,5 , and $1 \%$ levels respectively.

$$
\text { I II III IV }
$$

Variable Total Speculation (production) Total Speculation (reserves)

Panel A: Using Altman's Z-score as bankruptcy probability measure

\begin{tabular}{|c|c|c|c|c|}
\hline Firm size & $\begin{array}{c}-0.0301 * * \\
(-2.088)\end{array}$ & $\begin{array}{l}0.0135 \\
(1.661)\end{array}$ & $\begin{array}{c}-0.00561 * * \\
(-2.440)\end{array}$ & $\begin{array}{c}-0.00324 \\
(-0.869)\end{array}$ \\
\hline Z score & $\begin{array}{c}-0.0725 * * * \\
(-3.396)\end{array}$ & $\begin{array}{c}-0.0503^{* *} \\
(-2.180)\end{array}$ & $\begin{array}{c}-0.0308 * * * \\
(-2.779)\end{array}$ & $\begin{array}{l}-0.0256 \\
(-1.151)\end{array}$ \\
\hline$Z$ score $^{2}$ & $\begin{array}{l}0.0105 * * * \\
(2.989)\end{array}$ & $\begin{array}{c}0.00653 * \\
(1.934)\end{array}$ & $\begin{array}{l}0.00452 * * \\
(2.465)\end{array}$ & $\begin{array}{c}0.00394 \\
(1.059)\end{array}$ \\
\hline Board size & $\begin{array}{c}0.0113 * \\
(1.931)\end{array}$ & $\begin{array}{l}-0.00535 \\
(-1.601)\end{array}$ & $\begin{array}{l}0.00268 * * \\
(2.234)\end{array}$ & $\begin{array}{c}0.00216 \\
(1.228)\end{array}$ \\
\hline Outside director ratio & $\begin{array}{l}0.0852 \\
(0.787)\end{array}$ & $\begin{array}{l}-0.00431 \\
(-0.0640)\end{array}$ & $\begin{array}{l}0.0181 \\
(0.830)\end{array}$ & $\begin{array}{l}0.0220 \\
(0.604)\end{array}$ \\
\hline Staggered dummy & $\begin{array}{c}-0.0492 * * \\
(-2.045)\end{array}$ & $\begin{array}{l}0.0154 \\
(0.690)\end{array}$ & $\begin{array}{c}0.000508 \\
(0.0442)\end{array}$ & $\begin{array}{c}0.00825 \\
(0.583)\end{array}$ \\
\hline CEO - Chair duality & $\begin{array}{l}-0.0225 \\
(-0.801)\end{array}$ & $\begin{array}{c}-0.00720 \\
(-0.283)\end{array}$ & $\begin{array}{c}-0.00334 \\
(-0.550)\end{array}$ & $\begin{array}{c}0.00434 \\
(0.533)\end{array}$ \\
\hline CEO tenure & $\begin{array}{l}-0.00132 \\
(-0.830)\end{array}$ & $\begin{array}{c}-0.000200 \\
(-0.148)\end{array}$ & $\begin{array}{c}-0.000491 \\
(-0.942)\end{array}$ & $\begin{array}{c}7.66 \mathrm{e}-05 \\
(0.155)\end{array}$ \\
\hline Institutional ownership & $\begin{array}{c}-0.00784 \\
(-0.187)\end{array}$ & $\begin{array}{l}-0.0237 \\
(-1.063)\end{array}$ & $\begin{array}{l}-0.00885 \\
(-0.738)\end{array}$ & $\begin{array}{c}-0.00678 \\
(-0.600)\end{array}$ \\
\hline $\begin{array}{l}\text { Log (delta of CEO } \\
\text { compensation) }\end{array}$ & $\begin{array}{l}0.0219 \\
(1.675)\end{array}$ & & $\begin{array}{c}0.00181 \\
(0.797)\end{array}$ & \\
\hline $\begin{array}{l}\text { Log (vega of CEO } \\
\text { compensation) }\end{array}$ & $\begin{array}{l}-0.0104 \\
(-0.856)\end{array}$ & & $\begin{array}{c}-0.000916 \\
(-0.490)\end{array}$ & \\
\hline $\begin{array}{l}\text { Log (delta of CFO } \\
\text { compensation) }\end{array}$ & & $\begin{array}{l}0.0286 \\
(1.393)\end{array}$ & & $\begin{array}{c}-0.00368 \\
(-0.859)\end{array}$ \\
\hline $\begin{array}{l}\text { Log (vega of CFO } \\
\text { compensation) }\end{array}$ & & $\begin{array}{l}-0.0305 \\
(-1.492)\end{array}$ & & $\begin{array}{c}0.000778 \\
(0.224)\end{array}$ \\
\hline Intercept & $\begin{array}{c}0.134 \\
(1.559)\end{array}$ & $\begin{array}{l}0.0984 \\
(1.330)\end{array}$ & $\begin{array}{l}0.0572 * * * \\
(3.082)\end{array}$ & $\begin{array}{c}0.0605 * * \\
(2.165)\end{array}$ \\
\hline Observations & 91 & 46 & 153 & 80 \\
\hline R-squared & 0.313 & 0.362 & 0.209 & 0.147 \\
\hline
\end{tabular}


Table 6 -- Continued

\begin{tabular}{|c|c|c|c|c|}
\hline Variable & $\begin{array}{c}\mathrm{V} \\
\text { Total Specu } \\
\end{array}$ & $\begin{array}{c}\text { VI } \\
\text { n (production) }\end{array}$ & $\begin{array}{c}\text { VII } \\
\text { Total Speculation } \\
\end{array}$ & $\begin{array}{c}\text { VIII } \\
\text { (reserves) }\end{array}$ \\
\hline \multicolumn{5}{|c|}{ Panel B: Using Ohlson's O-score as bankruptcy probability measure } \\
\hline \multirow{2}{*}{ Firm size } & -0.0341 & 0.0128 & $-0.00968 * *$ & -0.00669 \\
\hline & $(-1.622)$ & $(1.016)$ & $(-2.206)$ & $(-1.083)$ \\
\hline \multirow{2}{*}{ O score } & 0.0184 & $0.0385 * * *$ & 0.00125 & 0.00131 \\
\hline & $(1.511)$ & $(8.455)$ & $(0.619)$ & $(0.712)$ \\
\hline \multirow{2}{*}{ O score ${ }^{2}$} & 0.00438 & $-0.00649 * * *$ & $-9.54 \mathrm{e}-05$ & 0.000206 \\
\hline & $(1.625)$ & $(-4.880)$ & $(-0.205)$ & $(0.583)$ \\
\hline \multirow{2}{*}{ Board size } & 0.00882 & -0.00400 & 0.00260 & 0.00113 \\
\hline & $(1.195)$ & $(-1.300)$ & $(1.445)$ & $(0.641)$ \\
\hline \multirow{2}{*}{ Outside director ratio } & 0.107 & -0.0221 & 0.0305 & 0.0693 \\
\hline & $(0.834)$ & $(-0.309)$ & $(0.818)$ & $(1.146)$ \\
\hline \multirow{2}{*}{ Staggered dummy } & -0.0448 & 0.0284 & -0.00260 & 0.00341 \\
\hline & $(-1.545)$ & $(1.272)$ & $(-0.265)$ & $(0.337)$ \\
\hline \multirow{2}{*}{ CEO - Chair duality } & 0.00592 & -0.00246 & 0.00251 & 0.00667 \\
\hline & $(0.176)$ & $(-0.198)$ & $(0.341)$ & $(0.945)$ \\
\hline \multirow{2}{*}{ CEO tenure } & -0.000263 & 0.000327 & -0.000128 & 0.000487 \\
\hline & $(-0.174)$ & $(0.267)$ & $(-0.218)$ & $(0.608)$ \\
\hline \multirow{2}{*}{ Institutional ownership } & 0.00695 & -0.0381 & -0.00504 & -0.0106 \\
\hline & $(0.172)$ & $(-1.532)$ & $(-0.487)$ & $(-0.916)$ \\
\hline \multirow{2}{*}{$\begin{array}{l}\text { Log (delta of CEO } \\
\text { compensation) }\end{array}$} & 0.0121 & & -0.000745 & \\
\hline & $(0.982)$ & & $(-0.336)$ & \\
\hline \multirow{2}{*}{$\begin{array}{l}\text { Log (vega of CEO } \\
\text { compensation) }\end{array}$} & -0.00475 & & 0.00101 & \\
\hline & $(-0.377)$ & & $(0.716)$ & \\
\hline \multirow{2}{*}{$\begin{array}{l}\text { Log (delta of CFO } \\
\text { compensation) }\end{array}$} & & 0.0250 & & -0.00226 \\
\hline & & $(1.288)$ & & $(-0.688)$ \\
\hline \multirow{2}{*}{$\begin{array}{l}\text { Log (vega of CFO } \\
\text { compensation) }\end{array}$} & & -0.0312 & & 0.000388 \\
\hline & & $(-1.403)$ & & $(0.134)$ \\
\hline \multirow{2}{*}{ Intercept } & 0.108 & 0.102 & 0.0456 & 0.0172 \\
\hline & (1.077) & (1.188) & $(1.371)$ & $(0.636)$ \\
\hline Observations & 94 & 50 & 153 & 81 \\
\hline R-squared & 0.169 & 0.462 & 0.079 & 0.093 \\
\hline
\end{tabular}

